\title{
Efektifitas Model Discovery Learning Terhadap Hasil Belajar siswa pada Pembelajaran Tematik Terpadu Usia 7-8 tahun
}

\author{
Hendrizal1 ${ }^{1}$, Vivi Puspita ${ }^{\circledR}$, Riwayati Zein ${ }^{3}$ \\ Pendidikan Guru Sekolah Dasar, Sekolah Tinggi Keguruan dan Ilmu Pendidikan Adzkia(1,2) \\ Pendidikan Guru Pendidikan Anak Usia Dini, Sekolah Tinggi Keguruan dan Ilmu \\ Pendidikan Adzkia(3) \\ DOI: $\underline{10.31004 / o b s e s i . v 6 i 2.1280}$
}

\begin{abstract}
Abstrak
Hasil belajar merupakan tolak ukur keberhasilan proses pembelajaran yang dilakukan. Hasil belajar di sekolah dasar khususnya pengetahuan masih rendah. Penelitian ini mengukur pengaruh penerapan model discovery learning terhadap hasil belajar pengetahuan siswa pada pembelajaran tematik di sekolah dasar. Penelitian ini merupakan penelitian eksperimen dengan dalam bentuk quasy eksperimental design. Desain quasy eksperimen yang digunakan dalam penelitian ini yaitu nonequivalent control group design. Satu kelas menggunakan model pembelajaran saintific dan kelas percobaan menggunakan discovery learning. Subjek penelitian adalah keseluruhan siswa kelas II SD N 26 Jati Utara Kota Padang. Instrumen pengumpulan data dengan menggunakan tes. Berdasarkan hasil uji hipotesis dengan menggunakan uji-t diperoleh data sebagai berikut. Terdapat perbedan hasil belajar antara siswa siswa yang menggunakan model discovery learning dengan siswa yang memperoleh pembelajaran dengan pendekatan saintific. Dengan demikian model discovery learning dapat digunakan pada pembelajaran tematik guna meningkatkan hasil belajar pengetahuan siswa.
\end{abstract}

Kata Kunci: hasil belajar; discovery learning; tematik terpadu

\begin{abstract}
Learning outcomes are a benchmark for the success of the learning process carried out. Learning outcomes in elementary schools, especially knowledge, are still low. This study measures the effect of the application of the discovery learning model on student learning outcomes in thematic learning in elementary schools. This research is an experimental research in the form of a quasi experimental design. The quasi-experimental design used in this study is a nonequivalent control group design. One class uses a scientific learning model and an experimental class uses discovery learning. The research subjects were all second grade students of SD N 26 North Jati Padang City. The instrument of data collection was using a test. Based on the results of hypothesis testing using the $t$-test, the following data were obtained. There are differences in learning outcomes between students who use the discovery learning model and students who get learning with a scientific approach. Thus the discovery learning model can be used in thematic learning to improve student learning outcomes.
\end{abstract}

Keywords: learning outcome; discovery learning; thematic learning

Copyright (c) 2021 Hendrizal, Vivi Puspita, Riwayati Zein

$\triangle$ Corresponding author :

Email Address : vivipuspita.pendas@gmail.com (Padang, Indonesia

Received 20 April 2021, Accepted 15 may 2021, Published 21 June 2021 


\section{PENDAHULUAN}

Pembelajaran merupakan proses kegiatan belajar mengajar yang berperan dalam menentukan keberhasilan belajar siswa. Dari proses pembelajaran itu akan terjadi sebuah kegiatan timbal balik antara guru dengan siswa dalam memperoleh tujuan yang lebih baik. Pembelajaran yang dapat menciptakan tujuan yang lebih bermakna adalah pembelajaran tematik terpadu, hal tersebut sesuai dengan pendapat Marsali (2016) bahwa penggunaan tema digunakan sebagai pemersatu mata pelajaran dan menekankan pada makna dalam proses pembelajaran. Mardi (2016) menyampaikan bahwa dengan penyajian pembelajaran sacara utuh maka mempermudah siswa dalam memahami materi pembelajaran. Dengan demikian pembelajaran tematik terpadu adalah pembelajaran terpadu (integrated) yang dapat dilaksanakan pada semua mata pelajaran. Tematik terpadu memandang bahwa suatu pokok bahasan harus terpadu secara menyeluruh. Keterpaduan ini dapat dicapai melalui pemusatan pelajaran pada satu masalah tertentu dengan alternatif pemecahan melalui berbagai disiplin ilmu atau mata pelajaran yang diperlukan. Sehingga batas-batas antara mata pelajaran dapat ditiadakan.

Aktivitas yang dilakukan oleh siswa dalam proses pembelajaran merupakan salah satu faktor penting yang sangat mempengaruhi ketercapaian tujuan pembelajaran. Menurut Widodo \& Widayanti (2014) aktivitas artinya kegiatan atau keaktifan, Jadi segala sesuatu yang dilakukan atau kegiatan-kegiatan yang terjadi baik fisik maupun non-fisik selama proses pembelajaran merupakan suatu aktivitas. Aktivitas siswa selama proses belajar mengajar merupakan salah satu indikator adanya keinginan siswa untuk belajar. Berdasarkan pengertian tersebut yang dimaksud dengan aktivitas belajar adalah segala sesuatu yang dilakukan oleh siswa baik fisik maupun mental/non fisik dalam proses pembelajaran atau suatu bentuk interaksi (guru dan siswa) untuk memperoleh suatu perubahan tingkah laku dalam mencapai tujuan pembelajaran. dibutuhkan suatu model pembelajaran yang dapat menunjang proses pembelajaran tematik terpadu yang berlandaskan pada pendekatan Scientific.

Hasil observasi yang telah dilakukan pada pembelajaran tematik di kelas II menunjukkan pelaksanaan tematik dengan mengaitkan beberapa mate pelajaran, yaitu bahasa Indonesia, PKn, Matematika, dan IPA. Dalam pelaksanaannya diperoleh temuan sebagai berikut; 1) Pembelajaran dominan menggunakan metode ceramah, menyebabkan terjadinya komunikasi satu arah dari guru terhadap peserta didik yang menyebabkan peserta didik menjadi kurang aktif dan hanya menerima informasi dari guru saja. 2) Penguasaan materi diukur dengan tes hasil belajar dan merupakan prestasi peserta didik dalam pembelajaran. Akan tetapi prestasi dan hasil belajar matematika peserta didik belum seperti yang diharapkan. 1) guru cenderung memulai pembelajaran dengan menyajikan materi pembelajaran, 2) pembelajaran masih berupa penyelesaian latihan dan jawaban yang terdapat pada buku siswa, 3) masih dominannya peran guru dalam proses pembelajaran, 4) proses pembelajaran hanya berupa tanya jawab antara guru dengan beberapa siswa; 5) pembelajaran belum mengembangkan aktivitas siswa dalam mengemukakan pendapat, mengajukan pertanyaan bahkan menyebabkan aktivitas negatif siswa seperti bermain dan berjalan-jalan di kelas. 6) kurang terlihatnya interaksi berbagai arah, seperti siswa dengan guru atau siswa dengan siswa lainnya dalam proses pembelajaran; 7) Waktu pelaksanaan pembelajaran menjadi lebih singkat dari pada waktu perencanaan, dan 8) Pada akhir pembelajaran belum melibatkan siswa dalam menyimpulkan pelajaran.

Berdasarkan permasalahan yang dipaparkan, terlihat kesenjangan yang terjadi dalam pembelajaran tematik terpadu. Hal tersebut memunculkan permasalahan yang perlu diatasi. Salah satu model yang sesuai dengan permasalahan adalah dengan menggunakan model discovery learning. Model pembelajaran merupakan suatu perencanaan atau suatu pola yang digunakan sebagai pedoman dalam merencanakan pembelajaran di kelas, atau pembelajaran dalam tutorial dan untuk menentukan perangkat-perangkat pembelajaran termasuk di dalamnya buku-buku, film, komputer, kurikulum,dan lain-lain. Abdullah (2017) mengatakan 
bahwa setiap model pembelajaran mengarah kepada desain pembelajaran untuk membantu peserta didik sedemikian rupa sehingga tujuan pembelajaran tercapai.

Model discovery learning menurut Ana (2019) merupakan suatu model pembelajaran yang dapat membantu siswa dalam mengasimilasi suatu konsep atau prinsip. Tayeb (2017) menjelaskan model sebagai prosedur yang sistematis yang dilaksanakan selama proses pembelajaran. Dengan demikian dalam pembelajaran model dapat membantu guru dalam mengasimilasi materi pembelajaran melalui langkah-langkah yang memudahkan yang memudahkan siswa. Ulni \& Suparno (2020) dalam penelitiannya yang menggunakan model discovery yang berbeda yakni sorting predict-think discovery efektif untuk meningkatkan kemampuan mengenal pola warna dan bentuk pada anak usia 5-6 tahun.

Model pembelajaran yang dapat digunakan selain saintifik pada sekolah dasar adalah discovery learning. Lieung (2019) menjelaskan bahwa discovery learning dapat membantu siswa dalam membangun pengetahuan secara mandiri. Proses ini memberikan kesempatan kepada siswa untuk memahami materi sesuai dengan pengetahuan awal dan pengalaman yang dimilikinya. Lieung (2019) menjelaskan bahwa model discovery adalah cara penyajian yang banyak melibatkan siswa dalam proses-proses mental dalam penemuannya terhadap suatu materi, sehingga dapat memfasilitasi siswa dalam mengamati, mencerna, mengerti, menggolong-golongkan, membuat dugaan, menjelaskan, mengukur dan membuat kesimpulan dalam usaha memahami suatu materi. Dalam pelaksanaan siswa dapat memperoleh pengalaman langsung untuk mengembangkan kompetensinya agar mampu menjelajahi dan memahami alam sekitar secara ilmiah, sehingga dengan model discovery learning dapat meningkatkan kualitas, proses dan pencapaian tujuan pembelajaran. Dari hasil peneletian terdahulu, berkaitan model pembelajaran discovery learning diperoleh temuan bahwa langkah-langkah yang digunakan baru hanya sebatas sintak discovery learning versi Nugrahaeni et al. (2017) berupa enam langkah yang meliputi 1) Stimulation, 2) Problem statement, 3) Data collection, 4) Data prossesing, 5) Verifikasi, dan 6) Generalisasi. Sejatinya, dalam penerapan pembelajaran menggunakan discovery learning menerapkan langkahlangkah pembelajaran. Penerapan discovery learning dalam pembelajaran tematik terpadu di sekolah dasar

Pemaparan di atas mengindikasi bahwa discovery learning dapat mendorong siswa untuk lebih mengembangkan, memperbanyak kesiapan, serta penguasaan keterampilan dalam proses kognitif pengenalan siswa. Proses discovery learning yang melibatkan aktivitas mental menimbulkan pengetahuan yang bersifat sangat pribadi/individual sehingga dapat kokoh/mendalam tertinggal dalam jiwa siswa. Kegiatan tersebut juga dipercaya untuk mampu memberikan kesempatan kepada siswa untuk berkembang dan maju sesuai dengan kemampuannya masing-masing, Mampu mengarahkan cara siswa belajar, sehingga lebih memiliki motivasi yang kuat untuk belajar giat. Selanjutnya dapat Membantu siswa untuk memperkuat dan menambah kepercayaan pada diri sendiri dengan proses penemuan sendiri.

Kegiatan discovery learning yang berorientasi penemuan dipercaya dapat membangkitkan kegairahan belajar siswa. Hal tersebut berlandaskan pada permasalahan yang digunakan dalam discovery learning merujuk pada permasalahan yang ditemui dalam kehidupan, sehingga siswa merasakan pembelajaran yang bermakna. Selanjutnya pembelajaran yang berpusat pada siswa, tidak lagi pada guru. Guru hannya sebagai teman belajar dan membantu bila diperlukan memberikan dampak kemandirian dan kepercayaan diri bagi siswa dan menjalin komunikasi yang baik antar-siswa maupun dengan guru.

Berdasarkan penjelasan di atas jelaslah bahwa discovery learning tidak hanya membantu siswa dalam menguasai materi pembelajaran melalui proses penemuan, tetapi discovery learning juga memfasilitasi guru dalam menanamkan karakter kepada siswa. Asumsinya adalah melalui kegiatan penemuan akan menimbulkan karakter yang membuat siswa memiliki integritas, jujur, dan loyal. Melalui kegiatan discovery learning siswa juga dapat membentuk pola pikir terbuka serta tidak suka memanfaatkan orang lain. Melalui interaksi dalam discovery learning akan dapat membentuk karakter atau sikap peduli dan 
perhatian terhadap orang lain maupun kondisi sosial lingkungan sekitar sehingga siswaakan dapat menghargai dan menghormati orang lain. Pembelajaran dengan discovery learning membutuhkan pola pikir yang sistematis, kritis dan analitis akan menunjang pembentukan rasa bertanggung jawab, disiplin, dan selalu melakukan sesuatu dengan sebaik mungkin.

Berdasarkan penjelasan di atas, jelaslah bahwa model discovery learning dapat diterapkan pada pembelajaran tematik terpadu serta dapat menunjang proses pembelajaran yang mengacu pada pendekatan scientifik. Oleh karena itu peneliti tertarik untuk melakukan penelitian dengan menggunakan model discovery learning sehingga dapat meningkatkan aktivitas dan proses pembelajaran tematik terpadu.

\section{METODOLOGI}

Jenis penelitian yang digunakan dalam penelitian ini adalah penelitian kuantitatif. Metode penelitian yang digunakan dalam penelitian ini adalah penelitian eksperimen. Desain penelitian eksperimen yang digunakan dalam penelitian ini adalah dalam bentuk quasy eksperimental design. Quasy eksperimental design mempunyai kelompok kontrol tetapi tidak dapat berfungsi sepenuhnya untuk mengontrol variabel-variabel luar yang mempengaruhi pelaksanaan eksperimen. Desain quasy eksperimen yang digunakan dalam penelitian ini yaitu nonequivalent control group design

Penelitian ini didesain menjadi dua kelas yaitu kelas eksperimen dan kelas kontrol. Kelas eksperimen diberi perlakuan dengan mengunakan model Discovery learning sedangkan kelas kontrol menggunakan pembelajaran saintifik. Diberikan postest kepada kedua sampel untuk melihat ada tidaknya pengaruh model Discovery learning terhadap aktivitas belajar siswa pada pembelajaran tematik terpadu. Subjek penelitian ini adalah siswa kelas II-A SD Negeri 26 Jati Kecamatan Padang Utara Kota Padang untuk kelas eksperimen dan kelas II-B SD Negeri 26 Jati Kecamatan Padang Utara.

Variabel bebas yang digunakan dalam penelitian ini adalah penerapan model discovery learning. Sedangkan Variabel terikat dalam penelitian ini adalah hasil belajar siswa II-A SD Negeri 26 Jati Kecamatan Padang Utara Kota Padang untuk kelas eksperimen dan kelas II-B SD Negeri 26 Jati Kecamatan Padang Utara. Instrumen penelitian adalah alat yang digunakan untuk mngumpulkan data. Dalam penelitian ini digunakan beberapa instrument yang di perlukan, di antaranya yaitu Rencana Pelaksanaan Pembelajaran (RPP), kisi-kisi soal, soal tes, dan kunci jawaban tes.

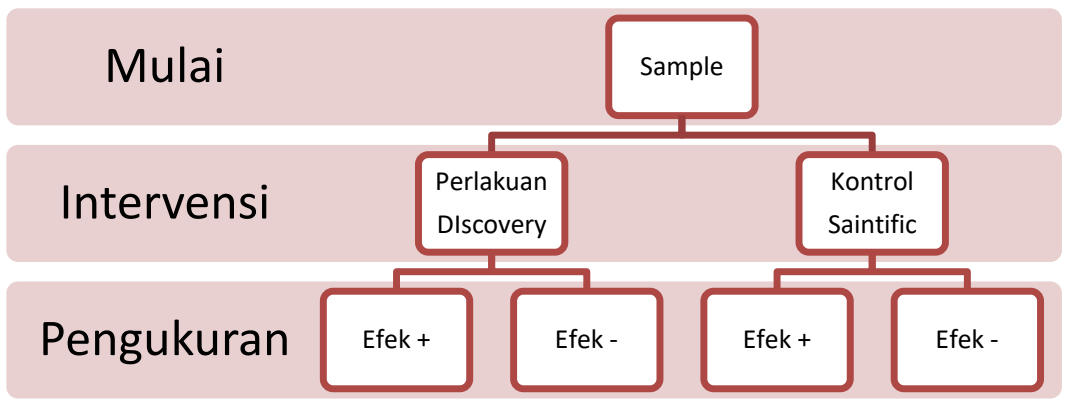

Bagan 1 Desain Penelitian

Validitas adalah ukuran yang menunjukkan tingkat kevalidan atau kesahihan suatu instrumen. Instrumen dikatan valid jika dapat digunakan untuk mengukur apa yang seharusnya diukur. Jadi instrumen yang valid merupakan syarat mutlak untuk mendapatkan hasil penelitian yang valid. Validasi yang diukur adalah validasi isi dan validasi item, Sebuah tes dikatakan memiliki validasi isi apabila mengukur tujuan khusus tertentu yang sejajar dengan materi atau isi pelajaran yang diberikan. Oleh karena itu, materi yang diajarkan tertera pada kurikulum, maka validitas isi sering disebut validitas kurikuler. Pengujian validasi dalam penelitian ini dilakukan melalui pertimbangan para ahli (expert judgement), penulis 
meminta pendapat dari tim ahli, yaitu Dr. Jendriadi,M.Pd , Dr. Riwayati Zein,M.Pd dan Meri Amrieti, M.Pd. Berdasarkan hasil validasi ahli nantinya akan diperoleh kesimpulan bahwa ada soal yang relevan, direvisi atau bahkan di buang. Sebelum tes dilaksanakan di kelas eksperimen dan kontrol, tes perlu diuji cobakan. Uji coba ini dimaksudkan agar diperoleh instrumen yang sahih (valid) dan andal (realible). Sehingga nantinya diperoleh hasil penelitian yang valid dan reliable. Setelah uji coba tes dilakukan, maka dilanjutkan dengan analisis untuk melihat apakah keberadaan suatu soal itu baik atau tidak. Agar soal yang digunakan dapat memenuhi kriteria sebagai alat ukur yang baik, maka diteliti validitas, reliabilitas, tingkat kesukaran soal dan daya pembeda soal.

Analisis soal antara lain bertujuan untuk mengadakan identifikasi soal yang baik dan identifikasi soal yang jelek. soal dikatakan baik jika item soal tersebut telah diberikan kepada siswa dan mampu menggambarkan perbedaan anak yang pandai dan anak yang kurang pandai. Langkah-langkah yang dilakukan untuk menganalisis item soal tes adalah: Uji Validitas, Uji Reliabilitas. Teknik pengumpulan data merupakan langkah yang paling strategis dalam penelitian, Uji Normalitas, Uji normalitas data bertujuan untuk mengetahui apakah data digunakan berdistribusi normal atau tidak. Pada perhitungan ini, Uji Homogenitas. Uji homogenitas tujuannya adalah untuk mengetahui apakah kelas sampel mempunyai variansi yang homogen atau tidak. Uji Hipotesis, Uji hipotesis bertujuan untuk melihat apakah hasil belajar tematik terpadu siswa yang menerapkan model pembelajaran Discovery Learning peneliti menggunakan uji $\mathrm{t}$ untuk menguji hipotesis apabila data berdistribusi normal dan mempunyai variansi homogen

Rumus uji t adalah sebagai berikut:

$$
t=\frac{\overline{X_{1}}-\overline{X_{2}}}{S \sqrt{\frac{1}{n_{1}+\frac{1}{n_{2}}}}} \quad \text { dengan } \quad S=\sqrt{\frac{\left(n_{1}-1\right) s_{1}^{2}+\left(n_{2}-1\right) s_{2}^{2}}{n_{1}+n_{2}-2}}
$$

\section{HASIL DAN PEMBAHASAN}

Hasil belajar dapat dilakukan setelah pelaksanaan pembelajaran dengan menggunakan instrumen penilaian, yakni tes hasil belajar (postest) siswa pada pembelajaran tematik terpadu sesudah perlakuan (treatment) diberikan. Kegiatan penelitian dilaksanakan dari tanggal 15 - 29 April 2019 di kelas II-A sebagai kelas eksperimen dan kelas II-B sebagai kelas kontrol SD Negeri 26 Jati Kecamatan Padang Utara Kota Padang. Kelas eksperimen diberi treatment dengan menggunakan pembelajaran tematik terpadu model discovery learning, sedangkan pada kelas kontrol tidak diberikan treatment apapun artinya tetap menggunakan pembelajaran yang biasa digunakan oleh guru dalam mengajar yaitu menggunakan pendekatan saintific. (Armadi, 2017) menjelaskan langkah saintifict memuat kegiatan mengamati, menanya, mengumpulkan informasi, mengasosiasikan dan mengkomunikasikan. Treatment yang berbeda di antara kelas eksperimen dengan kelas kontrol dimaksudkan untuk mengetahui pengaruh yang ditimbulkan terhadap hasil belajar siswa.

Pembelajaran di kelas eksperimen dengan menggunakan pembelajaran tematik terpadu dengan model discovery learning. Pelaksanaan pembelajaran menggunakan pembelajaran tematik terpadu model discovery learning di kelas eksperimen pada penelitian dimulai dengan guru mengucap salam, mengkondisikan kelas, memeriksa kehadiran siswa, membaca do'a belajar bersama-sama, dan membuka pembelajaran. Sebelum proses pembelajaran dimulai guru terlebih dahulu menyampaikan tujuan pembelajaran yang ingin dicapai siswa dan memotivasi siswa dalam proses pembelajaran. Selanjutnya dilakukan proses kegiatan inti.

Pertama stimulasi/pemberian rangsangan, pernyataan/ identifikasi masalah, guru memberikan stimulasi atau memberikan ransangan dengan pertanyaan yang berkaitan dengan materi. Siswa juga diberikan teks bacaan yang dapat menimbulkan pertanyaan bagi 
siswa. Ketika siswa mulai bertanya-tanya tentang materi yang dibahas, siswa digiring untuk menyelidiki sendiri apa yang menjadi pertanyaan baginya. Sehingga siswa berusaha untuk memecahkan permasalahan yang ia hadapi. (Purwaningrum, 2016)

Kedua, siswa mendapatkan kesempatan dari guru untuk mengidentifikasi sebanyak mungkin dengan agenda permasalahan yang relevan dengan materi yang sedang dibahas. Pengidentifikasian masalah yang dilakukan oleh siswa diarahkan ke dalam tiga pertanyaan utama, selanjutnya siswa membuat hipotesisnya sendiri yang berkaitan dengan permasalahan yang sedang dibicarakan. Siswa mendapatkan kesempatan untuk mengidentifikasi dan menganalisa permasasalahan yang mereka hadapi, sehingga siswa terbiasa untuk menemukan jawaban dari masalah yang dihadapinya (Hidayat et al., 2019) Ketiga pengumpulan data, siswa berkelompok dan mulai mengumpulkan informasi yang relevan dari berbagai sumber tentang permasalahan yang sedang dikaji. Siswa melakukannya bertujuan untuk membuktikan benar atau tidaknya hipotesis yang sudah dibuatnya. Sehingga siswa mengetahui kebenaran tentang benar tidaknya hipotesis. Berbagai aktivitas dilakukan oleh siswa sesuai dengan materi yang dibahas di pertemuan tersebut, seperti membaca literatur, mengamati objek, wawancara dengan narasumber, dan melakukan uji coba sendiri.

Keempat pengolahan data, siswa mengolah data dan informasi yang telah diperoleh dengan wawancara, observasi, dan membaca, lalu ditafsirkan. Semua informasi hasil bacaan, wawancara, dan observasi diolah, diacak, diklasifikasikan, ditabulasikan, dihitung, dan ditafsirkan dengan cara memasukkannya ke dalam tabel dan kolom kusus hasil temuan dan dideskripsikan siswa. Sehingga siswa mendapatkan pengetahuan baru dari temuan datanya.Kelima pembuktian, siswa melakukan pemeriksaan secara cermat untuk membuktikan benar atau tidaknya hipotesis yang ditetapkan diawal pembelajaran dengan temuan alternatif yang dilakukannya. Hipotesis dikaitkan dengan hasil data oleh siswa. Sehingga siswa kreatif untuk menemukan pemahaman konsep sendiri. Keenam menarik kesimpulan/generalisasi, siswa menarik sebuah kesimpulan yang dijadikan prinsip umum dan berlaku untuk semua kejadian atau masalah yang sama dalam pertemuan tertentu dengan materi yang berbeda. Setelah menarik kesimpulan, siswa memperhatikan proses generalisasi yang menekankan pentingnya penguasaan pembelajaran atas makna dan kaidah atau prinsipprinsip yang luas yang mendasari pengalaman mereka, serta serta mengarahkan siswa tentang pentingnya proses pengaturan dan generalisasi dari pengalaman-pengalaman yang mereka lalui dalam proses penemuannya. Kemudia siswa mempresentasikan ke depan kelas dihadapan temannya untuk mengomunikasikan hasil temuannya. Siswa dengan bimbingan guru menyimpulkan materi yang telah dipelajari setelah semua kelompok selesai mempresentasikan tugasnya didepan kelas. Kegiatan akhir pada pembelajaran yaitu gurumenutup pelajaran dengan membaca do'a setelah belajar dan salam. Pembelajaran di kelas kontrol tanpa menggunakan model pembelajaran tematik terpadu model discovery learning dan pendidikan karakter

Pelaksanaan pembelajaran dengan tidak menerapkan model pembelajaran tematik terpadu model discovery learning dan pendidikan karakter di kelas kontrol dalam penelitian ini dengan langkah-langkah sebagai berikut: guru membuka pembelajaran dengan mengucapkan salam, mengkondisikan kelas, menanyakan kabar siswa, mengecek kehadiran siswa, memberikan apersepsi, selanjutnya guru menyampaikan tujuan pembelajaran, dan memotivasi siswa dalam proses belajar.

Pada tahap eksplorasi, siswa melakukan tanya jawab dengan guru mengenai materi yang sedang dibahas. Kemudian siswa mendiskusikan dengan teman sebangkunya mengenai materi. Selanjutnya guru memberikan latihan berupa soal evaluasi kepada siswa. Pada tahap konfirmasi, guru menjelaskan kembali secara ringkas mengenai materi atau tugas yang belum dipahami siswa, serta memberi kesimpulan tentang materi pelajaran yang telah dipelajari. Kegiatan akhir pada pembelajaran yaitu menutup pelajaran dengan membacakan do'a setelah belajar dan salam. 
Pertemuan terakhir, pada hari Sabtu 29 April 2019 guru memberikan tes akhir (posttest) berupa soal pilihan ganda 15 butir pada kelas eksperimen dan kelas kontrol dengan tujuan untuk melihat hasil belajar siswa. Setelah hasil tes diperoleh maka dilanjutkan dengan menganalisis data tes akhir tersebut.

\section{Data Tes Hasil Belajar}

Pengumpulan data mengenai hasil belajar siswa dilakukan dengan instrumen tes akhir. Tes akhir berupa tes hasil belajar siswa yang berbentuk soal pilihan ganda yang terdiri dari 15 butir soal. Selanjutnya diberikan kepada kedua kelas sampel yang diikuti oleh 60 siswa, 30 siswa kelas eksperimen dan 30 siswa kelas kontrol. Tes diberikan kepada kedua kelas pada tanggal 29 April 2019 dan pada waktu yang sama, yaitu mulai dari jam $09.00 \mathrm{~s} / \mathrm{d} 10.00$ (60 menit).

Setelah dilaksanakan tes akhir, diperoleh data tentang hasil belajar siswa untuk materi tema 9 subtema 1 dan 2. Tes diberikan pada kelas II-A yang melaksanakan pembelajaran menggunakan model pembelajaran tematik terpadu model discovery learning dan tes juga diberikan pada kelas IV-B yang melaksanakan pembelajaran tanpa menggunakan model pembelajaran tematik terpadu model discovery learning dan pendidikan karakter. Nilai hasil tes akhir untuk kelas eksperimen dan kelas kontrol dapat dilihat dari tes akhir diperoleh nilai rata-rata $(\overline{\mathrm{x}})$, simpangan baku $(\mathrm{S})$, skor tertinggi $\left(\mathrm{x}_{\text {maks }}\right)$ dan skor terendah $\left(\mathrm{x}_{\min }\right)$ untuk kedua kelas sampel yang dinyatakan pada Tabel 4.23. hasil perhitungan data hasil belajar siswa berikut.

Tabel 1. Hasil Perhitungan Data Hasil Belajar

\begin{tabular}{llllll}
\hline Kelas & $\overline{\mathrm{X}}$ & $\mathrm{N}$ & Sx & Xmax & Xmin \\
\hline Eksperimen & 79,6 & 30 & 11,76 & 100 & 53 \\
Kontrol & 73,2 & 30 & 10,80 & 93 & 53 \\
\hline
\end{tabular}

Berdasarkan Tabel 1 terlihat bahwa rata-rata hasil belajar menggunakan model pembelajaran tematik terpadu model discovery learning dan pendidikan karakter siswa kelas eksperimen $(\overline{\mathrm{x}}=79,6)$ lebih tinggi dari rata-rata hasil belajar tanpa menggunakan model pembelajaran tematik terpadu model discovery learning dan pendidikan karakter siswa kelas kontrol $(\overline{\mathrm{x}}=73,2)$. Simpangan baku kelas eksperimen $(\mathrm{Sx}=11,76)$ lebih kecil dari simpangan baku kelas kontrol $(S x=10,80)$. Hal ini menunjukkan bahwa pada kelas eksperimen memiliki keragaman yang kecil, sehingga menyebabkan nilai siswa tersebar tidak terlalu jauh dari nilai rata-rata kelas. Selanjutnya perolehan skor tertinggi dan terendah antara kelas eksperimen dan kelas kontrol memiliki skor yang berbeda. Skor tertinggi siswa pada kelas eksperimen $\left(\mathrm{x}_{\mathrm{maks}=100}\right)$ lebih tinggi daripada kelas kontrol $\left(\mathrm{x}_{\mathrm{maks}}=93\right)$, demikian pula jika dilihat dari skor terendah yang diperoleh siswa pada kelas eksperimen $\left(\mathrm{x}_{\min =53}\right)$ sama dengan skor pada kelas kontrol $\left(\mathrm{x}_{\min =53}\right)$.

Di samping itu, jumlah ketuntasan siswa di kelas eksperimen lebih banyak dari kelas kontrol. Hal ini dapat dilihat pada Tabel 2 ..

Tabel 2. Nilai Ketuntasan Siswa pada Kelas Eksperimen dan Kelas Kontrol

\begin{tabular}{llll}
\hline Kelas & Jumlah Siswa & \multicolumn{3}{l}{ Persentase Ketuntasan } \\
Jumlah & $\%$ \\
\hline Ekperimen & 30 & 18 & 60 \\
Kontrol & 30 & 12 & 40 \\
\hline
\end{tabular}

Berdasarkan Tabel 2, terlihat bahwa persentase ketuntasan siswa kelas eksperimen lebih tinggi dari persentase ketuntasan siswa kelas kontrol. Pada kelas eksperimen, jumlah siswa yang tuntas ada 18 siswa atau $60 \%$ dan yang tidak tuntas ada 12 siswa atau $40 \%$ dari 
jumlah keseluruhan siswa kelas eksperimen yaitu 30 siswa. Sedangkan pada kelas kontrol 12 siswa atau $40 \%$ yang tuntas dan 18 siswa atau $60 \%$ tidak tuntas dari 30 siswa.

Sebelum kesimpulan dari data hasil belajar diambil, dilakukan analisis secara statistik terlebih dahulu. Analisis tersebut dilakukan dengan uji-t. Sebelum uji-t dilakukan, terlebih dahulu dilakukan uji normalitas dan uji homogenitas. Uji normalitas bertujuan untuk mengetahui apakah data yang diperoleh dari sampel berdistribusi normal atau tidak. Uji normalitas ini dilakukan dengan menggunakan program SPSS 21. Diperoleh hasil seperti Tabel 3.

Tabel 3. Hasil Uji Normalitas Tes Hasil Belajar Kelas Sampel Tests of Normality

\begin{tabular}{lllll}
\hline \multicolumn{2}{c}{ KELAS } & \multicolumn{3}{c}{ Kolmogorov-Smirnova } \\
\cline { 3 - 5 } NILAI & Statistic & df & Sig. \\
& B &, 157 & 30 &, 058 \\
& B 157 & 30 &, 053
\end{tabular}

a. Lilliefors Significance Correction

Berdasarkan Tabel 3. nilai signifikan yang diperoleh pada keterangan kolom Kolmogorof-Smirnov $>0,05$, dengan perolehan nilai signifikan kelas A 0,058>0,05 dan kelas B dengan nilai siginifikan 0,053>0,05. Maka dapat dikatakan bahwa data hasil belajar IPA siswa berdistribusi normal. Perhitungan uji homogenitas variansi kedua kelas sampel dengan menggunakan uji Levene dapat dilihat pada Tabel 4 .

Tabel 4. Hasil Uji Homogenitas Tes Hasil Belajar Kelas Sampel Test of Homogeneity of Variances

\begin{tabular}{cccc}
\multicolumn{5}{c}{ NILAI } \\
\hline Levene Statistic & df1 & df2 & Sig. \\
\hline 2,851 & 1 & 58 &, 097 \\
\hline
\end{tabular}

Berdasarkan Tabel 4. df1= jumlah kelompok data -1 atau 2-1=1, df2 = jumlah data jumlah kelompok data atau $60-2=58$ dan nilai signifikan yang peroleh yaitu 0,097>0,05,maka dapat dikatakan bahwa data hasil belajar siswa terdistribusi homogen. Setelah diketahui bahwa data kelas sampel berdistribusi normal danhomogen, maka selanjutnya dilakukan uji hipotesis dengan menggunakan uji-t. Hasil uji-t pada kedua kelas sampel dapat dilihat pada Tabel 5.

Tabel 5 Hasil Uji Hipotesis Tes Hasil Belajar Tematik Terpadu Kelas Sampel

\begin{tabular}{llllll}
\hline \multicolumn{1}{c}{ Kelas } & $\mathrm{N}$ & $\mathrm{X}$ & thitung & ttabel & $\alpha$ \\
\hline Ekspekrimen & 30 & 79,6 & 2,384 & 1,672 & 0,05 \\
Kontrol & 30 & 73,2 & & & \\
\hline
\end{tabular}

Berdasarkan Tabel 5. hasil uji hipotesis dengan menggunakan uji-t diperoleh data nila ithitung $=2,384$ dengan taraf kesukaran $5 \%$ dengan kriteria pengujian jika thitung $>$ ttabel maka tolak H0 dan terima H1. Dimana jumlah peserta tes di kelas eksperimensebanyak 30 siswa dengan rata-rata 79,6 sedangkan pada kelas kontrol jumlah peserta tes sebanyak 30 siswa dengan rata-rata 73,2. Perolehan nilai uji-t diperoleh thitung $=2,384$ lebih besar dari ttabel= 1,672 dengan $\mathrm{db}=58(\mathrm{n} 1+\mathrm{n} 2-2=30+30-2=58)$. Sehingga dapat disimpulkan bahwa: "hasil belajar siswa yang menggunakan model pembelajaran discovery learning terdapat pengaruh yang signifikan pada siswa yang tanpa menggunakan model pembelajaran discovery learning terintegrasi pendidikan karakter di kelas IV SD. Irdam Idrus \& Sri Irawati (2016) dalam penelitiannya menyatakan bahwa discovery learning dapat meningkatkan hasil belajar mulai dari 9-27 persen. Fitria (2018) menjelaskan bahwa peningkatan hasil siswa menggunakan 
model discovery learning pada pembelajaran tematik terpadu 15,75 persen dibandingkan kelas control hanya 5,21 persen.

Hasil tersebut menunjukkan bahwa penggunaan stimulasi berupa pemberian masalah dapat meningkatkan ketertarikan siswa untuk terlibat dalam pembelajaran. hal tersebut dipertegas oleh Purwaningrum (2016) bahwa pemberian masalah dapat mamantik siswa untuk memberikan respon terhadap pembelajaran. kegiatan. Problem statemen dapat mengembangkan pemahamasn siswa untuk dapat melakukan penalaran guna menbangun dan menghubungkan pengetahuan yang telah dimilikinya dengan permasalahan yang diajukan. Pada kegiatan ini siswa yang dberikan kontek nyata dapat menjelaskan dan memberikan gambaran tentang keterkaitan materi yang di pelajari dengan pengetahuan yang telah dimiliki sebelumnya.

Kegiatan pengumpulan data pada model discovery learning dapat membantu siswa untuk dapat berbagi pengalaman dengan teman. Menentukan pekerjaan masing-masing bertanggung jawab atas tugas yang telah diberikan. Kegiatan pengumpulan data dirancang dengan melibatkan aktifitas fisik maupun pikiran siswa, sehingga saat pembelajaran siswa terlibat langsung dalam memperoleh informasi. Selanjutnya kegiatan data prossesing yaitu siswa mendiskusikan dengan teman kelompok tentang hasil yang diperoleh. (Fitria, 2018) menjelaskan semakin banyak waktu yang diberikan kepada siswa maka akan sedikit kesalahan yang dilakukan oleh siswa. Hal tersebut tentunya memberikan kesempatan kepada siswa secara mandiri untuk dapat menyampaikan ide atau gagasan serta membandingkan gagasan dengan teman yang lain. Penelitian $\mathrm{M}$ et al. (2019) menjelaskan bahwa discovery learning memberikan kesempatan kepada siswa untuk dapat berdialog sehingga dapat bertukar ide atau gagasan melalui kegiatan berdiskusi. Tahap verifikasi pada model pembelajaran discovery memberikan kesempatan kepada siswa untuk melakukan kroscek terhadap hasil yang telah di peroleh. Apakah jawaban tersebut benar. Hal ini tentunya memberikan kesempatan kepada siswa untuk lebih teliti dalam menarik suatu kesimpulan. Dengan demikian pembelajaran discovery learning memberikan kesempatan kepada siswa untuk dapat membangun pengetahuan secara mandiri maupun kelompok (Niswatuzzahro et al., 2018).

\section{SIMPULAN}

Berdasarkan uji hipotesis maka penggunaan pendekatan discovery learning memberikan hasil yang lebih baik pada aspek ketercapaian hasil belajar disbanding penggunaan pendekatan saintific. Dengan demikian penggunaan model discovery learning di kelas II sekolah dasar memberikan dampak positif terhadap hasil belajar siswa.

\section{UCAPAN TERIMA KASIH}

Kami ingin mengucapkan terima kasih kepada promotor Sufyarma Marsidin, Aliasar, Elizar, yang telah memberikan bimbingan dan arahan dalam melakukan penelitian ini

\section{DAFTAR PUSTAKA}

Abdullah, A. (2018). Pendekatan dan Model Pembelajaran yang Mengaktifkan Siswa. Edureligia; Jurnal Pendidikan Agama Islam, 1(2), 45-62. https://doi.org/10.33650/edureligia.v1i2.45

Ana, N. Y. (2019). Penggunaan Model Pembelajaran Discovery Learning Dalam Peningkatan Hasil Belajaran Siswa Di Sekolah Dasar. Pedagogi: Jurnal Ilmu Pendidikan, 18(2), 56. https:// doi.org/10.24036/fip.100.v18i2.318.000-000

Armadi, A. (2017). Pendekatan scientific dalam pembelajaran tematik terpadu di SD. Autentik: Jurnal Pengembangan Pendidikan Dasar, 1(1), 55-67. 
Fitria, Y. (2018). Perubahan Belajar Sains Siswa Sekolah Dasar Pada Pembelajaran Terintegrasi (Terpadu) Melalui Model Discovery Learning. Jurnal Inovasi Pendidikan Dan Pembelajaran Sekolah Dasar, 2(2), 52. https:// doi.org/10.24036/jippsd.v2i2.102705

Hidayat, T., Mawardi, \& Astuti, S. (2019). Peningkatan Kemampuan Berpikir Kritis Dan Hasil Belajar Siswa Kelas Iv Melalui Model Pembelaran Discovery Learning Pada Tema Indahnya Keberagamandi Negeriku. Judika (Jurnal Pendidikan Unsika), 7(1), 1-9. https://doi.org/10.31764/pendekar.v1i1.353

Irdam Idrus, \& Sri Irawati. (2019). Analisis Model Pembelajaran Discovery Learning Dalam Meningkatkan Hasil Belajar Ipa-Biologi. Talenta Conference Series: Science and Technology (ST), 2(2). https:// doi.org/10.32734/st.v2i2.532

Lieung, K. W. (2019). Pengaruh Model Discovery Learning terhadap Keterampilan Berpikir Kritis Siswa Sekolah Dasar. Musamus Journal of Primary Education, 1(2), 073-082. https://doi.org/10.35724/musjpe.v1i2.1465

M, I., Rukli, R., \& Baharullah, B. (2019). Pengembangan Perangkat Pembelajaran Matematika Menggunakan Metode Discovery Learning berbasis GRANDER di Sekolah Dasar. Edumaspul: $\quad$ Jurnal $\quad$ Pendidikan, $127-139$. https://doi.org/10.33487/edumaspul.v3i2.147

Mardi, I. (2015). Peningkatan Kegiatan Pembelajaran Tematik Terpadu Dengan Menggunakan Pendekatan Scientific Di Kelas Iv Sd. Jurnal Pelangi, 8(1). https://doi.org/10.22202/jp.2015.v8i1.387

Marsali, A. (2016). Peningkatan Pembelajaran Tematik Terpadu Dengan Menggunakan Model Problem Based Learning Di Kelas Iv Sekolah Dasar. E-Jurnal Inovasi Pembelajaran SD, 1, 1-17. https:// doi.org/10.24114/esjpgsd.v5i1.3974

Niswatuzzahro, V., Fakhriyah, F., \& Rahayu, R. (2018). Penerapan Model Discovery Learning Berbantuan Media Audio Visual untuk Meningkatkan Literasi Sains Siswa Kelas 5 SD. Scholaria: Jurnal Pendidikan Dan Kebudayaan, 8(3), 273-284. https://doi.org/10.24246/j.js.2018.v8.i3.p273-284

Nugrahaeni, A., Redhana, I. W., \& Kartawan, I. M. A. (2017). Penerapan Model Pembelajaran Discovery Learning Untuk Meningkatkan Kemampuan Berpikir Kritis Dan Hasil Belajar Kimia. Jurnal Pendidikan Kimia Indonesia, 1(1), 23. https://doi.org/10.23887/jpk.v1i1.12808

Purwaningrum, J. P. (2016). Mengembangkan Kemampuan Berpikir Kreatif Matematis Melalui Discovery Learning Berbasis Scientific Approach. Refleksi Edukatika, 6(2), 145157. https:// doi.org/10.24176/re.v6i2.613

Tayeb, T. (2017). Analisis dan Manfaat Model Pembelajaran. Jurnal Pendidikan Dasar Islam, $4(02), 48-55$.

Ulni, E. K., \& Suparno, S. (2020). Pengembangan Model Pembelajaran Sorting Predict-think Discovery untuk Meningkatkan Kemampuan Mengenal Pola. Jurnal Obsesi : Jurnal Pendidikan Anak Usia Dini, 5(1), 303. https:/ / doi.org/10.31004/obsesi.v5i1.576

Widodo, W., \& Widayanti, L. (2014). Peningkatan Aktivitas Belajar dan Hasil Belajar Siswa dengan Metode Problem Based Learning pada Siswa Kelas VIIA MTs Negeri Donomulyo Kulon Progo Tahun Pelajaran 2012/2013. Jurnal Fisika Indonesia, 17(49), 32-35. https:// doi.org/10.22146/jfi.24410 